АКУ ШЕРСТВ
ИНЕКОЛОГИЯ
РЕПРОДУКЦИЯ

Включен в перечень ведущих

рецензируемых журналов и изданий ВАК

$2016 \cdot$ ToM $10 \cdot$ № 2

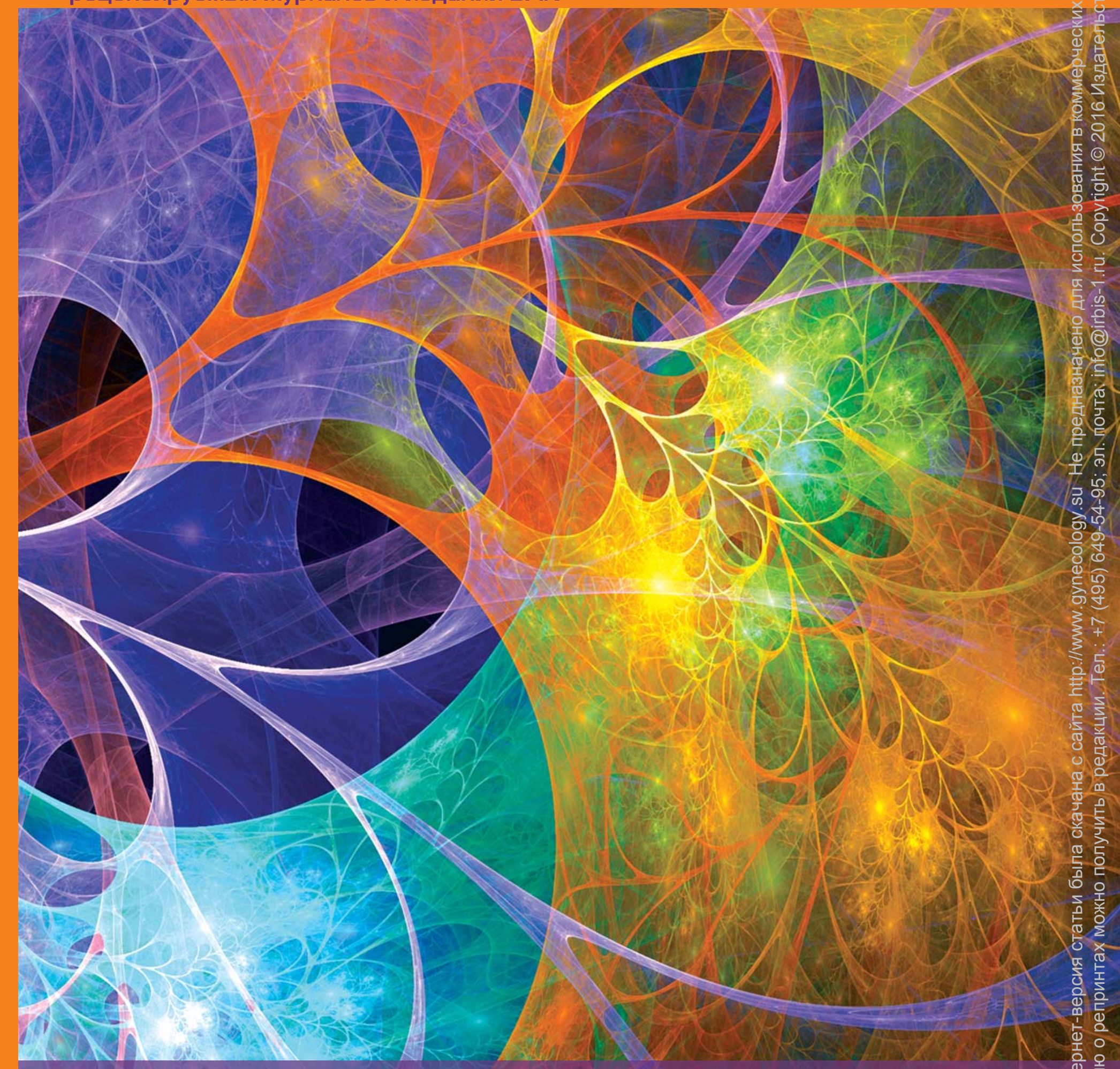

DBSTEIRICS, GYNECOLOGY AND REPRODUCTION竞

ISSN $2313-7347$

2016 Vol. 10 No 2 


\title{
SURROGACY - LEGAL AND BIOETHICAL ISSUES
}

\author{
Ponkina A.A. ${ }^{1}$, Ponkin I.V. ${ }^{2}$
}

${ }^{1}$ Institute of Church-State Relations and Law, Moscow

${ }^{2}$ Russian Presidential Academy of National Economy and Public Administration, Moscow

\section{Summary}

The article investigates the essence of the phenomenon of surrogacy (surrogate motherhood) from the standpoint of Bioethics and moral foundations of Law. Shows a selection of reference regulations of foreign Legislation. The authors present a Bioethical considerations of surrogacy and the most important issues related to the legal provision for surrogacy. Represented by the sample reference provisions of acts of a number of states (United States, Canada, Australia, United Kingdom, France, Russian Federation). The article suggests measures for improvement of the legislation of the Russian Federation in the context of restrictions to be imposed on the use of the surrogate motherhood technology.

\section{Key words}

Medical law, surrogacy (surrogate motherhood), mother rights, women's rights, children's rights, health care, right to health, public health management, comparative law, medicine.

Received: 08.02.2016; in the revised form: 29.04.2016; accepted: 24.06.2016.

\section{Conflict of interests}

The authors declared that they do not have anything to disclosure regarding funding or conflict of interests with respect to this manuscript.

All authors contributed equally to this article.

\section{For citation}

Ponkina A.A., Ponkin I.V. Surrogacy - legal and bioethical issues. Akusherstvo, ginekologiya i reproduktsiya / Obstetrics, gynecology and reproduction. 2016; 2: 70-76.

\section{Corresponding author}

Address: pr. Vernadskogo, 84, Moscow, Russia, 119606.

E-mail address: i@lenta.ru (Ponkin I.V.).

\section{СУРРОГАТНОЕ МАТЕРИНСТВО - ПРАВОВЫЕ И БИОЭТИЧЕСКИЕ РЕФЛЕКСИИ}

Понкина А.И. ${ }^{1}$, Понкин И.В. ${ }^{2}$

${ }^{1}$ Институт государственно-конфессиональных отношений и права, Москва

2 ФГБОУ ВПО «Российская академия народного хозяйства и государственной службы при Президенте

Российской Федерации», Москва 


\section{Резюме}

Статья посвящена исследованию сути френомена суррогатного материнства с позиций биоэтики и нравственных оснований права. Представлена выборка референтных положений зарубежного законодательства. Представлена выборка положений актов ряда государств (США, Канада, Австралия, Великобритания, Франция, Россия). В статье предложены меры по совершенствованию законодательства Российской Федерации в контексте ограничений, налагаемых на использование технологий суррогатного материнства.

\section{Ключевые слова}

Медицинское право, суррогатное материнство, права матери, права женщины, права ребенка, здравоохранение, право на охрану здоровья, государственное управления в области здравоохранения, сравнительное право, медицина.

Статья поступила: 08.02.2016 г.; в доработанном виде: 29.04.2016 г.; принята к печати: 24.06.2016 г.

\section{Конфликт интересов}

Авторы заявляют об отсутствии необходимости раскрытия ффинансовой поддержки или конфрликта интересов в отношении данной публикации.

Все авторы сделали эквивалентный вклад в подготовку публикации.

\section{Для цитирования}

Понкина А.И., Понкин И.В. Суррогатное материнство - правовые и биоэтические рефлексии. Акушерство, гинекология и репродукция. 2016; 2: 70-76.

\section{Introduction}

Over the past decade, a network of organizations has been established and is now actively developing in Russia that provide mediation services on a commercial basis for the arrangement of surrogate motherhood and related services for medical support of surrogate mothers. There is a whole industry the "production output" of which is only restricted by financial abilities of service consumers. However, the whole industry is more oriented to foreigners from countries where surrogacy is prohibited or highly restricted.

A lot of issues of legal regulation of surrogacy and related relations have not yet been convincingly substantiated, especially in terms of and for the purposes of bioethical imperatives and ethical bases for human rights and freedoms.

\section{Surrogacy legal regulation in the Russian Federation}

In the Russian Federation the legal provision for possible surrogacy was indirectly set out in Article 35 "Artificial Insemination and Embryo Implantation" of the Basic of Legislation of the Russian Federation for Health Protection dated July 22, 1993, as well as in Articles 51 and 52 of the Family Code of the Russian Federation dated December 29, 1995 (regarding embryo implantation into a surrogate mother for carrying the embryo), since there were no direct restrictions (or prohibitions) on surrogacy in these articles.

Today the application of the surrogacy method in the Russian Federation is governed by Article 55 "Application of Assisted Reproductive Technologies" of the Federal Law No. 323-FZ "On the Fundamentals of health protection in the Russian Federation" dated November 21, 2011 (hereinafter - Federal Law No. 323-FZ), according to which surrogacy is related to "assisted reproductive technologies" and "infertility treatment methods", and by Regulations of the Ministry of Public Health of the Russian Federation No.107n dated August 30, 2012.

As set out in paragraph 9 of Article 55 of the Federal Law No. 323-FZ "surrogacy means bearing and delivery of a child (including premature delivery) under a contract to be signed between the surrogate mother (the woman bearing the fetus after transfer of donor embryo) and the prospective parents, whose germ cells have been used for fertilization, or the single woman, who is unable to carry and deliver a child due to medical reasons". According to paragraph 10 of Article 55, "a woman aged from twenty to thirty five, having at least one healthy child of her own, who has obtained a medical certificate of good health, who has given written informed voluntary consent to medical intervention, may be a surrogate mother. A married woman, whose marriage is registered according to the procedure established by the legislation of the 
Russian Federation, may be a surrogate mother only upon written consent of her spouse. A surrogate mother cannot be simultaneously the ovule donor."

Analysis of the Federal Law No. 323-FZ, in conjunction with other regulatory acts, shows that the Russian legislation contains no restrictions on surrogate motherhood on a remuneration basis, thus making it legally possible to arrange the system of provision of commercial surrogacy services and develop the industry of these services, as evidenced by numerous facts of existence and development of this business. Advertisements specify the price of 15-20 thousand US dollars for surrogacy services. The price of $1,3 \mathrm{mln}$. rubles can also be found - for so called 'turnkey surrogacy.

Thus, the Federal Law No. 323-FZ (paragraphs 1, 9 and 10 of Article 55) objectively establishes legal conditions for organization of system of surrogacy industry.

\section{Bioethical considerations of surrogacy}

Though the issue of surrogacy, which may be provided 'in good faith' and on a non-commercial basis in exceptional cases, is very complex and ambiguous, it would be reasonable to give rational comments as to legal regulation in this area, including those of technical nature, as well as comments in terms of bioethics and the protection of public morality.

The term describing the relations in question is characteristic. Surrogate is a subject that only partially, by some properties, substitutes another subject.

Below we consider the most important issues related to the legal provision for surrogacy.

1. Surrogacy (especially if provided on a commercial basis, i.e. for remuneration to the surrogate mother and her mediator) is based on immoral and grossly infringing on the rights of women reduction, bringing down the value and role of the surrogate woman as a mother to the significance and role of a paid living incubator in the surrogacy industry, essentially - of means of production, transformation of a woman into a commercially operated 'human incubator'.

A number of foreign authors reasonably call surrogacy immoral business 'based on a woman's womb', 'uterus leasing', and 'womb for rent' technology $[4,11]$.

In one of the publications of the World Health Organization, a surrogate mother is called 'gestational carrier' and defined as follows: "gestational carrier is a woman in whom a pregnancy resulted from fertilization with third party sperm and oocytes. She carries the pregnancy with the intention or agreement that the offspring will be parented by one or both of the persons that produced the gametes" [9].

This situation is absolutely unacceptable, since it grossly infringes on the human dignity of a woman and her right to be a mother, contradicts with Articles 3 and 14 of the European Convention for the Protection of Human Rights and Fundamental Freedoms dated November 4, 1950, Articles 5 and 7 of the Universal Declaration of Human Rights dated December 10, 1948, Article 7 of the
International Covenant on Civil and Political Rights dated December 19, 1966, the Convention on the Elimination of All Forms of Discrimination against Women dated December 18, 1979, and a number of other international instruments on women's rights.

2. Surrogacy is based on the positioning of the child (to whose coming to life surrogate motherhood is oriented) as a legal object, a type of transaction subject matter rather than a person, in fact, as an inanimate object to which the attributes of goods and consumer properties of goods are assigned.

Not by chance in 1992 the Michigan Court of Appeals (USA), in the case No. 487 N.W.2d 484 "Doe v. Attorney General", in which a number of potential parties to surrogacy contracts tried to challenge the legislation of the State of Michigan that prohibited to enter into such contracts, emphasized that the prohibition on surrogacy aimed to protect several important state interests: first, prevention of a child from becoming an item of goods; second, adherence to the best interests of the child; and, third, prevention of the exploitation of women [10].

A number of foreign lawyers consider this type of commercial relations as distorting the nature of parental relations between mother and the child and as illegally infringing on the human dignity of women; they prove the validity of using the term 'child trafficking' to describe such commercial relations (See, for example: [4,11]).

3. Surrogacy is one of the types of sexual exploitation of women; this activity can be reasonably considered and evaluated as an analogue of prostitution while mediation in such activity as an analogue of trading in prostitution. These analogy can be substantiated by the fact that defenders "of the women's right to freely use their body" in prostitution are trying to influence public opinion in the same way saying that a woman can, at her sole discretion, choose how to use her own body and that it is a work that is on a par with other types of work activities and the woman shall be remunerated for these services just as for any other services.

4. Surrogacy flagrantly violates the rights of the child, particularly the right of the child to personal and family identity and related specific communication with his/her birthmother, since, according to numerous scientific researches, the infant child has a stable psychophysiological connection to his/her mother (who carried and gave birth to the child), and this connection is established as early as the prenatal stage of development of the child (in utero of his/her mother). Interruption of this connection causes significant stress and other adverse impacts for the child.

References to opposite conclusions made by other researches are unjustified since the results of such researches cannot be scientifically confirmed in a suitable manner in view of their fragmentary nature, non-referential case sampling such researches are based on, and, frequently, ideologically motivated biased (fitted) results. However, even the most objective researches of the effects of giving away the child who was born to a surrogate 
mother today do not give and, in principle, cannot give an overall picture of issues caused by surrogate motherhood.

The Basis of the Social Concept of the Russian Orthodox Church states that "'surrogate motherhood', that is, the bearing of a fertilized ovule by a woman who after the deliver returns the child to the 'customers', is unnatural and morally inadmissible even in those cases where it is realized on a non-commercial basis. This method involves the violation of the profound emotional and spiritual intimacy that is established between mother and child already during the pregnancy. 'Surrogate motherhood' traumatizes both the bearing woman, whose mother's feelings are trampled upon, and the child who may subsequently experience an identity crisis (BSC XII.4) [5].

5. Surrogacy that implies the exploitation of somebody else's body deprives the child of his/her own family and is generally destructive to the moral foundations of the family institution and the fundamental moral foundations of the society. In addition to the above analogy, this practice is also contingently comparable, actually and morally, with the admission of free commercial sales of human internals.

6 . If the child born by a surrogate mother is sick (with physical defects, abnormalities, severe internal diseases, etc.), customers of surrogacy services have the right (which is usually included in standard terms and conditions of the contract for surrogacy services) to resign such child (as some 'defective item' not meeting the initial agreements), which flagrantly violates the rights of the child and humiliates his/her dignity. In this situation the surrogate mother is also not protected at all and has no rights: the customers not only take away the child but, again according to the standard terms and conditions of the agreement, have the right to claim for 'compensation' to be paid by her, saying that she (the surrogate mother) is the only one guilty in that the child was born sick. In this case it would be extremely difficult (almost impossible) for the surrogate mother (given that her social standing is lower than that of customers of her services) to prove her innocence.

7. Commercial surrogacy business is immoral and inhuman and can be defined as an arrangement of child trafficking and mediation in such trafficking. The argument of surrogacy defenders, trying to substantiate social acceptability of commercial surrogacy services, that the compensation made by the surrogate mother is only the reimbursement of expenses incurred by her during pregnancy and in connection with bearing of someone else's child, has no basis since there is a significant difference between the surrogate motherhood on a commercial basis and non-commercial surrogate motherhood: the surrogate mother and, more importantly, the mediator are get paid (in fact, gain income) carrying on business.

8. Referring surrogacy to 'infertility treatment methods' has neither legal, nor logical, nor factual basis, taking into account the established semantic meaning of the term 'treatment'. Infertility cannot be treated by surrogacy since this method does not help get rid of infertility, while there is only contingent 'compensation' of adverse effects of infertility through delivery of the child using this technol- ogy. However, the woman customer of surrogacy services is still considered infertile, from a medical point of view, after the birth of the child to the surrogate mother.

We believe that the above reasons determine that the arrangement and implementation of surrogacy on a commercial basis as well as mediation in the arrangement of surrogacy are prohibited in most countries of the world, including in many US states. In many countries surrogacy is strictly prohibited.

It should also be noted that the current trend of growing interest to use the surrogacy technology by homosexual couples in order to 'get' children raises the issue of gross violation of children's rights in such situations.

\section{Legal regulation of surrogacy abroad: absolute prohibition on surrogacy}

In France the prohibition of surrogate motherhood is set out in Article 16-7 of the Civil Code of France [7]: "Any agreement relative to procreation or gestation on account of a third party is void" and is based on a number of regulations. For example, Article 227-12 of the French Penal Code [8] implies criminal responsibility for mediation and even for attempted mediation in such dealings (a penalty of up to 15 thousand Euro or imprisonment for 1 year; in some cases the penalty may be doubled).

According to article 541 of the Civil Code of Quebec (Canada) [6], "any agreement whereby a woman undertakes to procreate or carry a child for another person is absolutely nul".

According to Article 4 of the Federal Act of Switzerland "On Medically Assisted Reproduction" dated December 18, 1998 [12], "ovum and embryo donation and surrogate motherhood are prohibited".

In 1988 the Surrogate Parenting Act [16] was adopted in Michigan (USA) (Article 722.851-722.863 of the Michigan Compiled Laws) in order to recognize surrogacy contracts as conflicting with the national policy and void and to prohibit entering into surrogacy contracts for commercial purposes. As set out in Article 722.855 of the Michigan Compiled Laws (USA), "a surrogate parentage contract is void and unenforceable as contrary to public policy" [16]. Moreover, paragraph 1 of Article 722.857 of the Michigan Compiled Laws (USA) states that "a person shall not enter into, induce, arrange, procure, or otherwise assist in the formation of a surrogate parentage contract under which an unemancipated minor female or a female diagnosed as being intellectually disabled or as having a mental illness or developmental disability is the surrogate mother or surrogate carrier" [16].

Violation of the prohibition specified in paragraph 1 of Article 722.857 of the Michigan Compiled Laws (USA), according to paragraph 2 of this Article, is a felony and is punishable by a maximum fine of $\$ 50,000$ or imprisonment for up to 5 years, or both penalties shall apply [16].

According to $\S 122$ of Article 8 of the New York State Domestic Relations Law (USA) [13], "surrogate parenting contracts are hereby declared contrary to the public policy of this state, and are void and unenforceable". Part 
1 of $\S 123$ of Article 8 of the New York State Domestic Relations Law (USA) [13] sets out that no one shall knowingly request, accept, receive, pay or give any fee, compensation or other remuneration, directly or indirectly, in connection with any surrogate parenting contract, or induce, arrange or otherwise assist in arranging a surrogate parenting contract for a fee, compensation or other remuneration, except for some cases. According to paragraph 'a' of part 2 of $\S 123$ of Article 8 of the New York State Domestic Relations Law (USA) [13], a birth mother or her husband, a genetic father and his wife, and, if the genetic mother is not the birth mother, the genetic mother and her husband who violate this section shall be subject to a civil penalty not to exceed five hundred dollars.

\section{Legal regulation of surrogacy abroad: direct prohibition on any offer to provide and provision of mediation services for the arrangement and implementation of surrogacy services as well as advertising such services}

In the Netherlands, Belgium and many other countries any mediation (even on a non-commercial basis) in the arrangement and implementation of surrogacy is prohibited [3].

In particular, this prohibition is in force in Switzerland and Australia.

The Surrogacy Act 2010 No. 2 of Queensland (Australia) establishes the responsibility of third parties. For example, according to paragraph 1 of Article 58 of the Act, a person must not intentionally provide a technical, professional or medical service to another person if the person knows the other person is, or intends to be, party to a commercial surrogacy arrangement; or if the person provides the service with the intention of assisting the other person to become pregnant for the purpose of the arrangement. Any violation of this rule is punishable by a fine of up to 100 penalty units or imprisonment for up to three years. However, paragraph 2 of Article 58 sets out that a person does not commit an offence if the person provides a technical, professional or medical service to a woman after she has become pregnant [14].

Paragraph 1 of article 10 of the Surrogacy Act 2010 No. 102 of New South Wales (Australia) directly prohibits advertising of surrogacy arrangements and states following:

"a person must not publish any advertisement, statement, notice or other material that:

(a) states or implies that a person is willing to enter into, or arrange, a surrogacy arrangement, or

(b) seeks a person willing to act as a birth mother under a surrogacy arrangement, or

(c) states or implies that a person is willing to act as a birth mother under a surrogacy arrangement, or

(d) is intended, or is likely, to induce a person to act as a birth mother under a surrogacy arrangement.

Maximum penalty: (a) in the case of a commercial surrogacy arrangement $-2,500$ penalty units in the case of a corporation or 1,000 penalty units or imprisonment for 2 years (or both) in any other case, or

(b) in any other case - 200 penalty units in the case of a corporation or 100 penalty units in any other case" [15].

Article 31 of the Federal Act of Switzerland "On Medically Assisted Reproduction" dated December 18, 1998 sets out the following:

"1. Any person who uses an assisted reproductive technique in a surrogate mother shall be liable to a term of imprisonment or to a fine.

2. The same penalty shall apply to any person who acts as an intermediary for surrogate motherhood" [12].

\section{Legal regulation of surrogacy abroad: prohibition on commercial surrogacy relations}

According to part 1 of paragraph 2 of the Surrogacy Arrangements Act of the United Kingdom "An Act to regulate certain activities in connection with arrangements made with a view to women carrying children as surrogate mothers" dated July 16, 1985 [1], "no person shall on a commercial basis do any of the following acts in the United Kingdom, that is -

(a) initiate or take part in any negotiations with a view to the making of a surrogacy arrangement,

(b) offer or agree to negotiate the making of a surrogacy arrangement, or

(c) compile any information with a view to its use in making, or negotiating the making of, surrogacy arrangements ;

and no person shall in the United Kingdom knowingly cause another to do any of those acts on a commercial basis".

Parts 2- 9 of paragraph 2 of this Act of the United Kingdom complete the above statement making it more precise and establishing the responsibility for violation of the above prohibitions, thus creating legal obstacles to various tricks that evade such prohibitions.

The Surrogacy Act 2010 No. 102 of New South Wales (Australia) [15] was adopted in order to legitimate certain types of surrogacy contracts and to define the status of children born as a result of surrogate motherhood. Article 8 of the Act of New South Wales prohibits entering into a commercial surrogacy arrangement under the threat of maximum penalty of 2,500 penalty units, in the case of a corporation, or 1,000 penalty units or imprisonment for 2 years (or both), in any other case. However, this Article also implies such sanctions for an offer to conclude the surrogacy contract for commercial purposes. This article contains no indication as to who shall be punished for these actions, thus extending the prohibition to all potential parties to such a contract. According to paragraph 1 of Article 9 of the Surrogacy Act 2010 No. 102 of New South Wales (Australia), "the surrogacy contract" is a commer- 
cial surrogacy arrangement if the arrangement involves the provision of a fee, reward or other material benefit or advantage to a person for the person or another person agreeing to enter into or entering into the surrogacy arrangement, or giving up a child of the surrogacy arrangement to be raised by the intended parent or intended parents, or consenting to the making of a parentage order in relation to a child of the surrogacy arrangement. However, part 2 of this Article sets out that a surrogacy arrangement is not a commercial surrogacy arrangement if the only fee, reward or other material benefit or advantage provided for is the reimbursement of a birth mother's surrogacy costs [15].

Article 56 of the Surrogacy Act 2010 No. 2 of Queensland (Australia) No. 22010 [14] establishes that a person must not enter into or offer to enter into a commercial surrogacy arrangement. Maximum penalty for this consists of 100 penalty units or 3 years imprisonment. According to paragraph 1 of Article 57 of the Act of Queensland, a person must not give a payment, reward or other material benefit or advantage (other than the reimbursement of the birth mother's surrogacy costs) for a surrogate mother. Maximum penalty for this consists of 100 penalty units or 3 years imprisonment.

Part 2 of Article 57 of the Surrogacy Act 2010 No. 2 of Queensland (Australia) prohibits surrogate mothers from receiving any remuneration for the performance of their obligations under the relevant contract, which is punishable by a fine of up to 100 penalty units or imprisonment for up to three years.

According to Article 6 of the Assisted Human Reproduction Act of Canada in force since 2004 [2], "1.No person shall pay consideration to a female person to be a surrogate mother, offer to pay such consideration or advertise that it will be paid. 2. No person shall accept consideration for arranging for the services of a surrogate mother, offer to make such an arrangement for consideration or advertise the arranging of such services. 3. No person shall pay consideration to another person to arrange for the services of a surrogate mother, offer to pay such consideration or advertise the payment of it. 4 . No person shall counsel or induce a female person to become a surrogate mother, or perform any medical procedure to assist a female person to become a surrogate mother, knowing or having reason to believe that the female person is under 21 years of age".

These acts (which represent only a small part of a large amount of examples) absolutely clearly show that a legal state that respects and protects the rights of its citizens, values its international reputation and the trust of its citizens shall neither legitimate immoral business 'based on a woman's womb' nor legitimate the arrangement of prostitution or human trafficking.

\section{Some conclusions}

Continued legal possibilities of commercial surrogate motherhood in the Russian Federation are only provided for the benefit of a limited number of wealthy Russian citizens and foreigners who come to Russia for this purpose as well as very influential surrogacy business representatives, including mediators who actually exploit women being in a bad financial situation.

Parts 1, 9 and 10 of Article 55 of the Federal Law No. 323-FZ "On the Foundations of the Protection of Citizen's Health in the Russian Federation" dated November 21, 2011 do not meet the national interests of the Russian Federation and create conditions for immoral industry of surrogate motherhood services, which is based on the positioning of the child as a legal object, a type of transaction subject matter rather than a person. In fact, the child is positioned as an inanimate object having the attributes of goods and consumer properties of goods, while the role of a woman as a mother is reduced to the role of a paid living incubator in the surrogacy industry. In fact, the woman becomes a means of production.

We consider it necessary to take the following measures for improvement of the legislation of the Russian Federation in the context of restrictions to be imposed on the use of the surrogate motherhood technology:

- prohibition on making any offer and any advertisement as well as providing mediation services for arrangement, implementation and support of surrogate motherhood;

- prohibition on entering into surrogacy contracts on a commercial basis;

- exclusion of surrogate motherhood from 'infertility treatment methods'; enshrining in law that only a legally married opposite-sex couple surrogacy can use surrogate motherhood as one of 'assisted reproductive technologies' in exceptional cases, with medical support provided only in a state or municipal health organization of the relevant profile;

- prohibition on the use of surrogate motherhood for those who are not married (first of all, prohibition on the use of surrogacy services for single men);

- prohibition on any advertisement of surrogate motherhood services;

- establishment of the procedures for recognition of the relations between 'parents' who made use of surrogate motherhood services abroad and the children they get in this way as adopted (but not native-born);

- enshrining the right of the surrogate mother to refuse to give the child she carried and gave birth to, without remuneration of funds spent on her by third parties who decided to take advantage of surrogacy;

- admission (in the long term) of surrogate motherhood relations only between relatives (no further than cousins of one of the spouses who want to take advantage of surrogate motherhood).

In the future, surrogacy shall be absolutely prohibited in the Russian Federation (alternatively, surrogate motherhood shall only be possible in highly exceptional cases to be clearly defined in law). 


\section{References:}

1 Act to regulate certain activities in connection with arrangements made with a view to women carrying children as surrogate mothers (Surrogacy Arrangements Act 1985). URL: http://www.legislation.gov.uk/ ukpga/1985/49. Accessed: 01.02.16.

2. Assisted Human Reproduction Act. URL: http://laws-lois.justice.gc.ca/eng/ acts/a-13.4/FullText.html. Accessed: 01.02.16.

3. Avis de Comité Consultatif de Bioéthique № 30 du 5 juillet 2004 relatif à la gestationpour-autrui. URL: http://www.health.belgium. be. Accessed: 01.02.16

4. Banda Vergara A. Dignidad de la persona y reproducción humana asistida. Revista de Derecho. 1998; IX: 7-42.

5. Basis of the Social Concept of the Russian Orthodox Church.
URL: http://www.patriarchia.ru/db/ text/419128.html. Accessed: 01.02.16.

6. Civil Code of Québec. URL: http://www2 publicationsduquebec.gouv.qc.ca. Accessed: 01.02.16.

7. Code civil de la France. URL: http://www. legifrance.gouv.fr. Accessed: 01.02.16.

8. Code pénal de la France. URL: http://www. legifrance.gouv.fr. Accessed: 01.02.16.

9. Current Practices and Controversies in Assisted Reproduction / Report of a meeting on «Medical, Ethical and Social Aspects of Assisted Reproduction» held at WHO Headquarters in Geneva, Switzerland 17-21 September 2001 / Edited by Effy Vayena, Patrick J. Rowe, P. David Griffin. Geneva: World Health Organization, 2002.

10. Doe vs. Attorney General / Decision of the Michigan Court of Appeals of 1992 № 487 N.W.2d 484. URL: http://www.leagle.com.
Accessed: 01.02.16.

11. Gómez de la Torre Vargas M. La fecundación in vitro y la filiación. Santiago de Chile: Editorial Jurídica de Chile, 1993.

12. Loi fédérale sur la procréation médicalement assistée du 18 décembre 1998. URL: http://www.admin.ch/opc/fr/classifiedcompilation/20001938/index.html. Accessed: 01.02.16.

13. New York Domestic Relations. URL: http://law.onecle.com/new-york/domesticrelations/article8.html. Accessed: 01.02.16.

14. Surrogacy Act № 2 of 2010. URL: http://www.austlii.edu.au. Accessed: 01.02.16.

15. Surrogacy Act 2010 № 102. URL: http://www.legislation.nsw.gov.au. Accessed: 01.02.16.

16. Surrogate parenting Act № 199 of 1988. URL: http://www.legislature.mi.gov. Accessed: 01.02.16.

\section{About the authors:}

Ponkina Alexandra Alexandrovna - PhD (Law), Deputy Director of the Institute of relations between the State and religious denominations and Law, expert of the Consortium of experts on patients' rights (Moscow). Address: P0 box 49, Moscow, 117525. E-mail: droit.du. patient@gmail.com.

Ponkin Igor Vladislavovich - doctor of science (Law), professor of the Institute of Public Administration and Management of the Russian Presidential Academy of National Economy and Public Administration; professor of the Kutafin Moscow State Law University, State Professor. Address: pr. Vernadskogo, 84, Moscow, Russia, 119606. E-mail: i@lenta.ru.

\section{Сведения об авторах:}

Понкина Александра Александровна - к.ю.н., заместитель председателя правления Института государственно-консессиональных отношений и права, эксперт Консорциума специалистов по защите прав пациентов. Адрес: 117525, Москва, а/я 49. E-mail: droit.du.patient@gmail.com.

Понкин Игорь Владиславович - д.Ю.н., профессор кафедры государственного и муниципального управления Института государственной службы и управления РАНХиГС при Президенте РФ, профессор Московского государственного юридического университета им. 0.Е. Кутасрина (МГЮА). Адрес: 119606, Россия, г. Москва, проспект Вернадского, 84. E-mail: i@lenta.ru. 